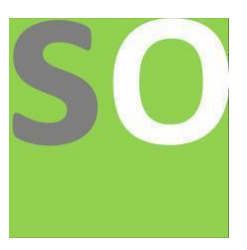

Article title: Factors influencing the place of delivery in the rural region of Labrousse, Hati

Authors: Herby MADDY[1], James Ernst Wil ST VIL[2], Eddy CEISTE[3], Deborah ALCIME[4]

Affiliations: Faculté de Médecine, Université Libre de Bruxelles, 1070 Anderlecht Belgique[1], Service de Pédiatrie, Hopital de L'Université d'Etat d'Haïti, Port-au-Prince, Haïti[2], Centre de Santé Notre Dame de Lourdes de Labrousse, Miragoane, Nippes, Haïti[3], Ecole de Santé Publique, Université Libre de Bruxelles, Campus Erasme, 1070 Anderlecht Belgique[4]

Orcid ids: 0000-0002-1719-4564[1]

Contact e-mail: herbymaddy@gmail.com

License information: This work has been published open access under Creative Commons Attribution License http://creativecommons.org/licenses/by/4.0/, which permits unrestricted use, distribution, and reproduction in any medium, provided the original work is properly cited. Conditions, terms of use and publishing policy can be found at https://www.scienceopen.com/.

Preprint statement: This article is a preprint and has not been peer-reviewed, under consideration and submitted to ScienceOpen Preprints for open peer review.

DOI: 10.14293/S2199-1006.1.SOR-.PPMIJJ4.v1

Preprint first posted online: 28 December 2021

Keywords: Healthcare Facility, Childbirth, Delivery place, Maternal Health, Haïti 


\section{Factors influencing the place of delivery in the rural region of Labrousse, Haïti}

Herby MADDY ${ }^{1,2}$, James Ernst Wil ST VIL ${ }^{3}$, Eddy CEISTE ${ }^{4}$, Deborah ALCIME ${ }^{2}$

${ }^{1}$ Master of Medicine student at the Faculty of Medicine of the Université Libre de Bruxelles, Belgium

${ }^{2}$ Master of Public Health student at the School of Public Health of the Université Libre de Bruxelles, Belgium

${ }^{3}$ Post Graduate doctor in Pediatrics at the hospital of the State University of Haiti

${ }^{4}$ Medical Director of the Notre Dame de Lourdes de Labrousse health center, Haiti

\section{ABSTRACT}

\section{Objectives}

The objective of this study is to determine factors that influence the place of delivery in the rural region of Labrousse, Haiti

\section{Design}

This study employed a cross-sectional survey design to collect data using an anonymous interview guide comprising structured questions and made up of two parts: 1- Identification of personal and socio-cultural parameters. 2-Identification of the reasons for the place of the last childbirth.

\section{Setting}

The study was conducted from September to November 2017 in Notre-Dame of Lourdes of Labrousse community health center and the area catered to by it. Labrousse is a rural community located in the 3rd communal section of Miragoâne about 19 kilometers from the main road, in the department of Nippes.

\section{Participants}

The survey included 92 women aged 13-46 years, live in the area who had at least one birth in the last $1-3$ years by the time of data collection.

\section{Results}

$75 \%$ of women gave birth to their last child at home. $76 \%$ of home births were assisted by a matron or traditional practitioner. age, religion, level of education of mothers and fathers, distance between home and health facility, availability of transportation and prenatal followup are significant factors $(P<0.05)$ that influence the choice of delivery place.

\section{Conclusion}

Acting on the factors influencing the delivery place in Labrousse would make it possible to bridge this gap between the number of home births and the number of births in healthcare facility. 


\section{INTRODUCTION}

\section{Background}

According to the World Health Organization, 500,000 women die each year because of their pregnancy, $99 \%$ in low- and middle-income countries. Home delivery remains one of the main causes of maternal and child mortality in these countries. Reducing maternal mortality is one of the elements of Goal 3 of the Sustainable Development Goals. One of the indicators to assess this process is the proportion of births performed by a trained health worker. Despite the progress made; in 2013, 289,000 women died during or after childbirth (1). In Haiti 6 out of 10 deliveries occur at home without medical assistance. Only $36 \%$ take place in a health facility $(21 \%$ in a public facility, $10 \%$ in a private facility and $5 \%$ in a mixed facility) (2). These proportions are higher in urban areas than in rural communities. (3). In urban areas, $63 \%$ of births took place with the help of a health worker compared to $30 \%$ in rural areas. $60 \%$ of births in urban areas occurs in a health facility compared to $29 \%$ in rural communities. (3). overall, several factors can influence delivery place $(4,5,6)$.

\section{Objectives}

The objective of this study is to determine factors that influence the place of delivery in the rural region of Labrousse, Haiti.

\section{METHODS}

\section{Study Setting}

The study was conducted from September to November 2017 in Notre-Dame of Lourdes of Labrousse community health center and the area catered to by it. Labrousse is a rural community located in the 3rd communal section of Miragoâne about 19 kilometers from the main road, in the department of Nippes. this mountainous region of about 15,000 inhabitants is divided into many small hamlets that are difficult to access and served by dirt roads with deep crevasses that meander through the mountains. Commonly seen economic activities of the zone are agricultural activities and livestock rearing. The zone has one health center and some dispensaries with roads that are difficult to use throughout the year.

\section{Study population}

The study population was women aged 13-46 years, live in the area who had at least one birth in the last $1-3$ years by the time of data collection. women who gave birth prematurely or 
who had been transferred to hospital due to a complication during childbirth were excluded from the study. The survey included 92 women

\section{Study design and data collection}

This study is a quantitative cross-sectional study. Data collection included interviews using an anonymous interview guide comprising structured questions and made up of two parts: 1Identification of personal and socio-cultural parameters. 2-Identification of the reasons for the place of the last childbirth. The questionnaire was developed after a rigorous review of the literature on the determinants of birthplace in similar studies. The variables studied are age, religion, level of education of mothers and fathers, parity, economic activity sector, marital status, distance between home and health facility, availability of transportation and prenatal follow-up.

\section{Data processing and analysis}

The data were analyzed using SPSS version 23 statistical software. frequency and proportion analyze were carried out to describe the socio-demographic and pregnancy characteristics of the study subjects. Pearson's correlation tests were used to assess the association between different variables. Those with a statistically significant association with the dependent variable were then evaluated with bivariate and multivariate logistic regressions to determine the magnitude of the correlation between the dependent and independent variables. $a$ confidence interval $=95 \%$ is considered with $p<0.05$ taken as statically significant association.

\section{RESULTS}

\section{characteristics of the study population}

The mean age of the respondents was $28.3 \pm 4.2$ with extremums of 17 and $43.2 .17 \%$ are Under 18. a high proportion (73.90\%) of mothers were in the age range of 19-32 years. $22.82 \%$ of respondents were married. $31.52 \%$ were primipara, $52.17 \%$ were multipara ( 2 to 3 children) and $16.30 \%$ were grand multipara (more than 3 children). Protestantism remains the dominant practice in this region (50\%), followed by Catholicism (44.56\%). $8.69 \%$ of women have never been to school; $50 \%$ have primary level; only $1.98 \%$ hold a professional study diploma. Retail business and agriculture are the two main economic activities of women in this region. the fathers were mainly farmers and motorcycle taxi drivers (53.26\%). 
$75 \%$ of women gave birth to their last child at home. $76 \%$ of home births were assisted by a matron or traditional practitioner. (Tab 1)

\begin{tabular}{|c|c|c|c|}
\hline VARIABLE & CATEGORY & FREQUENCY (N) & PERCENTAGE (\%) \\
\hline age group & $\begin{array}{l}=<18 \\
19-25 \\
26-32 \\
33=<\end{array}$ & $\begin{array}{l}2 \\
34 \\
34 \\
22\end{array}$ & $\begin{array}{l}2.17 \\
36.95 \\
36.95 \\
23.91\end{array}$ \\
\hline marital status & $\begin{array}{l}\text { Married } \\
\text { Unmarried }\end{array}$ & $\begin{array}{l}21 \\
71\end{array}$ & $\begin{array}{l}22.82 \\
77.17\end{array}$ \\
\hline parity & $\begin{array}{l}\text { Primipara } \\
\text { Multipara } \\
\text { Grand Multipara }\end{array}$ & $\begin{array}{l}29 \\
48 \\
15\end{array}$ & $\begin{array}{l}31.52 \\
52.17 \\
16.30\end{array}$ \\
\hline religion & $\begin{array}{l}\text { Catholicism } \\
\text { Protestantism } \\
\text { Voodoo } \\
\text { Others }\end{array}$ & $\begin{array}{l}41 \\
46 \\
1 \\
4\end{array}$ & $\begin{array}{l}44.56 \\
50 \\
1.08 \\
4.34\end{array}$ \\
\hline Mother's education level & $\begin{array}{l}\text { No education } \\
\text { Primary level } \\
\text { Secondary level } \\
\text { University level }\end{array}$ & $\begin{array}{l}8 \\
50 \\
33 \\
1\end{array}$ & $\begin{array}{l}8.69 \\
54.34 \\
35.86 \\
1.08\end{array}$ \\
\hline Father's education level & $\begin{array}{l}\text { No education } \\
\text { Primary level } \\
\text { Secondary level } \\
\text { University level }\end{array}$ & $\begin{array}{l}9 \\
42 \\
40 \\
1\end{array}$ & $\begin{array}{l}9.78 \\
45.65 \\
43.47 \\
1.08\end{array}$ \\
\hline $\begin{array}{l}\text { Mother's level of } \\
\text { economic activity }\end{array}$ & $\begin{array}{l}\text { No activity } \\
\text { Primary sector } \\
\text { Secondary sector } \\
\text { Tertiary sector }\end{array}$ & $\begin{array}{l}1 \\
36 \\
9 \\
46\end{array}$ & $\begin{array}{l}1.08 \\
39.13 \\
9.78 \\
50\end{array}$ \\
\hline $\begin{array}{l}\text { Father's level of } \\
\text { economic activity }\end{array}$ & $\begin{array}{l}\text { No activity } \\
\text { Primary sector } \\
\text { Secondary sector } \\
\text { Tertiary sector }\end{array}$ & $\begin{array}{l}0 \\
35 \\
8 \\
49\end{array}$ & $\begin{array}{l}0 \\
38.04 \\
8.69 \\
53.26\end{array}$ \\
\hline delivery place & $\begin{array}{l}\text { Healthcare Facility } \\
\text { Home }\end{array}$ & $\begin{array}{l}23 \\
69\end{array}$ & $\begin{array}{l}25 \\
75\end{array}$ \\
\hline $\begin{array}{l}\text { presence of matron } \\
\text { /traditional practitioner }\end{array}$ & $\begin{array}{l}\text { Yes } \\
\text { No }\end{array}$ & $\begin{array}{l}69 \\
23\end{array}$ & $\begin{array}{l}75 \\
25\end{array}$ \\
\hline
\end{tabular}

\section{Reasons for selection of place of delivery}

Of the various reasons mentioned, distance is an important element. $71.73 \%$ of respondents have no means of transport. $41.30 \%$ of women take about an hour, $32.60 \%$ walk for two hours and $26.08 \%$ walk for more than two hours to reach the nearest healthcare facility. The trip is most often done on foot (93.47\%). only $5.43 \%$ have access to a motorized vehicle. (Tab 2) 
Tab 2: Reasons for selection of place of delivery ( $\mathrm{N}=92)$

\begin{tabular}{|l|l|l|l|}
\hline VARIABLE & CATEGORY & FREQUENCY (N) & PERCENTAGE (\%) \\
\hline $\begin{array}{l}\text { Reasons for selection of } \\
\text { place of delivery }\end{array}$ & Any & 3 & 3.26 \\
& Distance & 66 & 71.73 \\
& Security & 15 & 16.30 \\
\hline distance from the & Pregnancy complication & 8 & 8.69 \\
healthcare facility & Fairly close (=<60 min walk) & 38 & 41.30 \\
& Distant (60-120 min walk) & 30 & 32.60 \\
\hline means of transport & very distant (120=<min walk) & 24 & 26.08 \\
\hline available & None (on foot) & 86 & 93.47 \\
& horseback & 1 & 1.08 \\
\hline & Motorcycle / car & 5 & 5.43 \\
\hline
\end{tabular}

\section{prenatal follow-up}

$91.30 \%$ of women made at least 2 antenatal visits with a regularity found in $84.78 \%$ of them. 73.91\% had 3 to 5 antenatal visits. (Tab 3)

\begin{tabular}{|c|c|c|c|}
\hline \multicolumn{4}{|c|}{ Tab 3: Prenatal Follow-up ( $\mathrm{N}=92)$} \\
\hline VARIABLE & CATEGORY & FREQUENCY (N) & PERCENTAGE (\%) \\
\hline \multirow[t]{2}{*}{ at least 2 antenatal visits } & Yes & 84 & 69.56 \\
\hline & No & 8 & 30.43 \\
\hline \multirow{2}{*}{$\begin{array}{l}\text { regularity of prenatal } \\
\text { visits }\end{array}$} & Yes & 78 & 84.78 \\
\hline & No & 14 & 15.21 \\
\hline \multirow{4}{*}{$\begin{array}{l}\text { number of antenatal } \\
\text { visits }\end{array}$} & $0-2$ & 8 & 8.69 \\
\hline & $3-5$ & 68 & 73.91 \\
\hline & $6-8$ & 13 & 14.13 \\
\hline & $>=9$ & 3 & 3.26 \\
\hline
\end{tabular}

Age is a statistically significant factor $(p<0.05)$ of home births. women aged 19-25 are more likely to give birth at home $(\mathrm{OR}=2.6 ; 95 \% \mathrm{Cl})$. Childbirth in healthcare facility, however, is not influenced by age $(p>0.05)$. Marital status and parity are not factors that can influence the choice of delivery place.

Catholic women are more likely to give birth at home (OR=1.06; $p=0.008 ; 95 \% \mathrm{Cl}$ ) while Protestant women are more likely to give birth in hospital (OR=1.12) (Tab 4). Mothers' level of education influences place of birth. those who have not been to school are more likely to give birth at home $(\mathrm{OR}=2.78 ; \mathrm{p}=0.001 ; 95 \% \mathrm{Cl})$. However, Mothers' level of education does not influence childbirth in hospital $(p>0.05)$. The fathers' level of education is decisive in the choice of the delivery place. The more educated they are, the more mothers give birth in a healthcare facility $(p=0.001)$ and conversely, the less educated they are, the more mothers give birth at home ( $p=0.004)$ (Tab 4). The parents' sector of economic activity is a determining 
factor of the delivery place. in the third sector, the probability for women to give birth at home was lower compared to other levels of economic activity, it positively influences healthcare facility childbirth $(O R=1.32 ; p=0.004 ; 95 \% \mathrm{Cl})$. The distance from the health center and the complications of subsequent pregnancies are statistically significant elements that influence the place of delivery. Women are more likely to give birth at home if they live far from the health center $(\mathrm{OR}=1.63 ; 95 \% \mathrm{Cl})$. the likelihood of giving birth at home increases if women do not have access to transportation $(\mathrm{OR}=18.8 ; 95 \% \mathrm{Cl})$. With a motorized vehicle available, they are more likely to give birth in a healthcare facility $(\mathrm{OR}=5 ; 95 \% \mathrm{Cl})(\mathrm{Tab} 5)$. antenatal visits influence the choice of delivery place. Women who have had more than 5 prenatal visits, whether regular or not, most often give birth in healthcare facility $(\mathrm{OR}=3.32 ; \mathrm{p}=0.009 ; 95 \% \mathrm{Cl})$ (Tab 6)

\begin{tabular}{|c|c|c|c|c|c|c|}
\hline \multicolumn{7}{|c|}{ Tab 4: multiple regression table (95\% IC) } \\
\hline \multirow[t]{3}{*}{ VARIABLE } & \multirow[t]{3}{*}{ CATEGORY } & \multirow{3}{*}{$\begin{array}{l}\text { FREQUENCY } \\
\text { (N) }\end{array}$} & \multicolumn{4}{|c|}{ DELIVERY PLACE (\%) } \\
\hline & & & \multicolumn{2}{|c|}{ Home } & \multicolumn{2}{|c|}{ Healthcare Facility } \\
\hline & & & OR & P-Value & OR & P-Value \\
\hline age group & $\begin{array}{l}=<18 \\
19-25 \\
26-32 \\
33=<\end{array}$ & $\begin{array}{l}2 \\
34 \\
34 \\
22\end{array}$ & $\begin{array}{l}0.33 \\
2.61 \\
0.54 \\
0.85\end{array}$ & 0.02 & $\begin{array}{l}3.09 \\
0.38 \\
1.83 \\
1.16\end{array}$ & 0.20 \\
\hline marital status & $\begin{array}{l}\text { Married } \\
\text { Unmarried }\end{array}$ & $\begin{array}{l}21 \\
71\end{array}$ & 0.58 & 0.75 & 1.71 & 0.30 \\
\hline parity & $\begin{array}{l}\text { Primipara } \\
\text { Multipara } \\
\text { Grand Multipara }\end{array}$ & $\begin{array}{l}29 \\
48 \\
15\end{array}$ & $\begin{array}{l}0.63 \\
1.00 \\
0.40\end{array}$ & 0.08 & $\begin{array}{l}1.57 \\
1.00 \\
2.46\end{array}$ & 0.20 \\
\hline religion & $\begin{array}{l}\text { Catholicism } \\
\text { Protestantism } \\
\text { Voodoo } \\
\text { Others }\end{array}$ & $\begin{array}{l}41 \\
46 \\
1 \\
4\end{array}$ & $\begin{array}{l}1.06 \\
0.89 \\
0.00 \\
0.00\end{array}$ & 0.00 & $\begin{array}{l}0.94 \\
1.12 \\
0.00 \\
0.00\end{array}$ & 0.008 \\
\hline $\begin{array}{l}\text { Mother's } \\
\text { education } \\
\text { level }\end{array}$ & $\begin{array}{l}\text { No education } \\
\text { Primary level } \\
\text { Secondary level } \\
\text { University level }\end{array}$ & $\begin{array}{l}8 \\
50 \\
33 \\
1\end{array}$ & $\begin{array}{l}2.48 \\
0.88 \\
0.53 \\
0.00\end{array}$ & 0.001 & $\begin{array}{l}0.40 \\
1.12 \\
1.87 \\
-----\end{array}$ & 0.08 \\
\hline $\begin{array}{l}\text { Father's } \\
\text { education } \\
\text { level }\end{array}$ & $\begin{array}{l}\text { No education } \\
\text { Primary level } \\
\text { Secondary level } \\
\text { University level }\end{array}$ & $\begin{array}{l}9 \\
42 \\
40 \\
1\end{array}$ & $\begin{array}{l}3.64 \\
0.56 \\
1.45 \\
0.00\end{array}$ & 0.01 & $\begin{array}{l}0.27 \\
1.75 \\
0.68 \\
-----\end{array}$ & 0.04 \\
\hline $\begin{array}{l}\text { Mother's level } \\
\text { of economic } \\
\text { activity }\end{array}$ & $\begin{array}{l}\text { No activity } \\
\text { Primary sector } \\
\text { Secondary sector } \\
\text { Tertiary sector }\end{array}$ & $\begin{array}{l}1 \\
36 \\
9 \\
46\end{array}$ & $\begin{array}{l}----- \\
1.00 \\
2.88 \\
0.70\end{array}$ & 0.001 & $\begin{array}{l}0.00 \\
1.00 \\
0.34 \\
1.41\end{array}$ & 0.006 \\
\hline $\begin{array}{l}\text { Father's level } \\
\text { of economic } \\
\text { activity }\end{array}$ & $\begin{array}{l}\text { No activity } \\
\text { Primary sector } \\
\text { Secondary sector } \\
\text { Tertiary sector }\end{array}$ & $\begin{array}{l}0 \\
35 \\
8 \\
49\end{array}$ & $\begin{array}{l}----- \\
1.03 \\
2.63 \\
0.75\end{array}$ & 0.0008 & $\begin{array}{l}-1--- \\
0.96 \\
0.37 \\
1.32\end{array}$ & 0.004 \\
\hline
\end{tabular}




\begin{tabular}{|c|c|c|c|c|c|c|}
\hline \multirow[t]{3}{*}{ VARIABLE } & \multirow[t]{3}{*}{ CATEGORY } & \multirow[t]{3}{*}{ FREQUENCY } & \multicolumn{4}{|c|}{ DELIVERY PLACE (\%) } \\
\hline & & & \multicolumn{2}{|c|}{ Home } & \multicolumn{2}{|c|}{ Healthcare Facility } \\
\hline & & & OR & P-Value & OR & P-Value \\
\hline $\begin{array}{lr}\text { Reasons for } \\
\text { selection } \\
\text { place } \\
\text { delivery }\end{array}$ & $\begin{array}{l}\text { Any } \\
\text { Distance } \\
\text { Security } \\
\text { Pregnancy complication }\end{array}$ & $\begin{array}{l}3 \\
66 \\
15 \\
8\end{array}$ & $\begin{array}{l}------ \\
----- \\
0.00 \\
0.00\end{array}$ & 0.02 & $\begin{array}{l}0.00 \\
0.00 \\
----- \\
-----\end{array}$ & 0.61 \\
\hline $\begin{array}{l}\text { distance from } \\
\text { the healthcare } \\
\text { facility }\end{array}$ & $\begin{array}{l}\text { Fairly close (=<60 min walk) } \\
\text { Distant ( } 60-120 \text { min walk) } \\
\text { very distant ( } 120=<\text { min walk) }\end{array}$ & $\begin{array}{l}38 \\
30 \\
24\end{array}$ & $\begin{array}{l}0.38 \\
1.63 \\
2.08\end{array}$ & 0.38 & $\begin{array}{l}2.56 \\
0.61 \\
0.48\end{array}$ & 0.15 \\
\hline $\begin{array}{l}\text { means of } \\
\text { transport } \\
\text { available }\end{array}$ & $\begin{array}{l}\text { None (on foot) } \\
\text { horseback } \\
\text { Motorcycle / car }\end{array}$ & $\begin{array}{l}86 \\
1 \\
5\end{array}$ & $\begin{array}{l}18.8 \\
-0.00\end{array}$ & 0.03 & $\begin{array}{l}0.05 \\
0.00 \\
------\end{array}$ & 0.14 \\
\hline
\end{tabular}

\begin{tabular}{|c|c|c|c|c|c|c|}
\hline \multicolumn{7}{|c|}{ Tab 6: regression table and significance of variables at the place of delivery ( $95 \%$ IC) } \\
\hline \multirow[t]{3}{*}{ VARIABLE } & \multirow[t]{3}{*}{ CATEGORY } & \multirow[t]{3}{*}{ FREQUENCY } & \multicolumn{4}{|c|}{ DELIVERY PLACE (\%) } \\
\hline & & & \multicolumn{2}{|c|}{ Home } & \multicolumn{2}{|c|}{ Healthcare Facility } \\
\hline & & & OR & P-Value & OR & P-Value \\
\hline at least 2 antenatal visits & $\begin{array}{l}\text { Yes } \\
\text { No }\end{array}$ & $\begin{array}{l}84 \\
8\end{array}$ & 5.7 & 0.925 & 0.17 & 0.39 \\
\hline regularity of prenatal visits & $\begin{array}{l}\text { Yes } \\
\text { No }\end{array}$ & $\begin{array}{l}78 \\
14\end{array}$ & 2.03 & 0.76 & 0.49 & 0.42 \\
\hline number of antenatal visits & $\begin{array}{c}0-2 \\
3-5 \\
6-8 \\
>=9\end{array}$ & $\begin{array}{l}8 \\
68 \\
13 \\
3\end{array}$ & $\begin{array}{l}0.35 \\
2.32 \\
0.30 \\
0.78\end{array}$ & 0.0007 & $\begin{array}{l}2.81 \\
0.43 \\
3.32 \\
1.28\end{array}$ & 0.009 \\
\hline
\end{tabular}

\section{DISCUSSION}

Pearson's correlation analyzes demonstrate that factors such as: age of mother, distance, available means of transportation, religion, educational level of mothers and fathers, their level of economic activity and complications of previous pregnancies are statistically significant factors influencing the choice of the delivery place in Labrousse. women aged 1925 are more likely to give birth at home $(O R=2.6 ; p=0.02 ; 95 \% \mathrm{Cl})$. Other studies on the subject show that, on the contrary, older women are more likely to give birth at home, unlike younger women who give birth in hospital [8]. The marital status of women does not influence the choice of delivery place ( $p=0.75$ at home; $p=0.30$ at healthcare facility) which corroborates the findings of other studies [7], [8]. The number of pregnancies and / or previous deliveries has no effect on the place of delivery; Primiparous, multiparous and grand multiparas give birth both in hospital and at home. In a study by Fritz Verly Vernet et al. The majority of primiparous gave birth in a hospital environment, while most multiparas and even more grand multiparas gave birth at home [9]. Diallo F, Diallo T, Sylla M et al. found similar results in a study they 
conducted in the tropics [16]. the Canadian Public Health Agency has established that nonhospital deliveries are more common among multiparas than first-time mothers [10]. Catholic women are more likely to give birth at home $(\mathrm{OR}=1.06 ; \mathrm{p}=0.008 ; 95 \% \mathrm{Cl})$ while Protestant women are more likely to give birth in hospital $(O R=1.12)$. Analyzes show that religion is a statistically significant element that can influence the place of delivery. other studies have shown that Christianity is indeed correlated with a high rate of hospital delivery [8] [11] [12]. The women's level of education influences the choice of delivery place. Only $12.5 \%$ of women who have never been to school gave birth in hospital compared to $87.5 \%$ at home; while $26.2 \%$ of those with an educational level gave birth in hospital against $71.4 \%$ who gave birth at home. mothers who have never been to school are more likely to give birth at home $(O R=2.78 ; p=$ 0.001). The fathers' level of education is also decisive on the choice of the delivery place, the more they are educated the more mothers give birth in the hospital $(p=0.001)$. Fritz Verly Vernet et al. found that over $78 \%$ of women who gave birth in hospital had reached secondary school and those who gave birth at home were mostly illiterate [9]. According to Faye A, Ndiaye P, Tal-Dia A, Bâ I.O. the more the woman's level of education increases, the more the chance of being assisted by qualified personnel during childbirth increases [13]. In Senegal; childbirth in a health institution by women at the primary and secondary level is respectively 1378 more and 3049 more that of women without instructions [13]. this could be explained by that the higher her level of education, the more the woman has the possibility of finding a better job and thus of having a high socioeconomic level and of having the means to give birth at hospital [14]. The level of economic activity of the parents is a determining factor of the delivery place. Thus we were able to find that in the tertiary sector of activity, the probability for these women to give birth at home was lower compared to other sectors of economic activity; it positively influences childbirth in hospital $(O R=1.32, p=0.004)$. studies have shown that women's economic health quintile plays a role in the birthplace $[7,8] . n$ this study, women are more likely to give birth at home if they are far from the health center, and this risk increases even more if there is no transport available. According to Faye A, Ndiaye P, Tal-Dia A, Bâ I.O, the prevalence of home birth was correlate to factors such as lack of transportation and long distance [13]. Confidence in health care providers can be a factor that can influence the choice of delivery place [9]. In our study, those who gave birth in healthcare facility in almost $100 \%$ of cases said they felt safe with health care providers, but this parameter was not evaluated in the correlation analysis. 
The results of this study have strengths and limitations. The census sampling technique and the high response rate add to the credibility of the results. However, the results should be interpreted with caution. The study setting could be different contextually with other rural parts of the country where there are more health services available. the cross-sectional nature of the study prevents elucidating the direction of the cause-and-effect relationship of the variables with the choice of delivery place.

\section{CONCLUSION}

in Haiti, the level of health service delivery in rural communities is significantly lower than in urban areas. This study shows the various factors that can influence the delivery place in Labrousse, it is necessary to act on these factors to close this gap that exists between the number of home deliveries and the number of healthcare facility deliveries for a reduction in maternal and infant mortality in rural areas. The Public Health Ministry and other relevant NGOs should work with organizations in the hinterland to facilitate expanded and integrated access to health care

\section{Ethical statements}

This study was carried out at the Notre Dame de Lourdes health center in Labrousse following the agreement of the managers of this center. The study was conducted under the supervision of the Ethical Medicine and Societal Laboratory (LABMES) of the Faculty of Medicine of the State University of Haiti. Each woman answered the questions individually, after informed consent, and a guarantee of confidentiality.

All authors have approved the final manuscript and agreed for its publication. This study has not received any allowance from any commercial or charitable agency or organization. The authors declare that there is no conflict of interest.

\section{REFERENCES}

1. De Browere V, Van Lerberghe W. Safe motherhood strategies: a review of the evidence studies in health services organization and policy. 200.

2. Cayemittes, Michel, Michelle Fatuma Busangu, Jean de Dieu Bizimana, Bernard Barrère, Blaise Sévère, Viviane Cayemittes et Emmanuel Charles. 2013. Enquête Mortalité, 
Morbidité et Utilisation des Services, Haïti, 2012. Calverton, Maryland, USA : MSPP, IHE et ICF International.

3. Institut Haïtien de l'Enfance (IHE) [Haïti] et ICF. 2017. Enquête Mortalité, Morbidité et Utilisation des Services, Haïti, 2016-2017: indicateurs Clés. Rockville, Maryland, et PétionVille, Haïti : IHE et ICF.

4. GSS,GHS,ICFInternational.Ghanademographicandhealthsurvey2014. Accra, Ghana: Ghana Statistical Service, Ghana Health Service, and ICF International.2015.

5. AghaS,CartonTW.Determinants of institutional delivery in rural Jhang, Pakistan. IntJ Equity Health. 2011;10(1):31.

6. MoyerCA, MustafaA. Drivers and deterrents of facility delivery in sub-Saharan Africa: asystematic review. ReprodHealth.2013;10(40).

7. A. Dev, C. Kivland, M. Faustin, O. Turnier, T. Bell, and M. D. Leger, "Perceptions of isolation during facility births in Haiti - a qualitative study," pp. 1-14, 2019.

8. S. Karanja et al., "Factors influencing deliveries at health facilities in a rural Maasai Community in," pp. 1-11, 2018.

9. Fritz V. Vernet, Angelson P. Theisme, Nelenda Laflèche, Joel Desir, Johny Rubin, Eddy Léandre, Sherley L. Facteurs influencant le lieu d'accouchement dans la commune de Lascahobas. La revue scientifique de la faculte de Médecine et de Pharmacie Ecole de Biologie Medicale Avril 2016, 2 : 19-23

10. Agence de la santé publique du Canada. Ce que disent: I'Enquête canadienne sur l'expérience de la maternité. http://www.phac-aspc.gc.ca

11. Khatri RB, Dangi TP, Gautam R, Shrestha KN, Homer CSE (2017) Barriers to utilization of childbirth services of a rural birthing center in Nepal: A qualitative study. PLoS ONE 12(5): e0177602.https://doi.org/10.1371/journal. pone.0177602. May 11, 2017.

12. Kim Choe M, Thapa S, Mishra V. Early marriage and early motherhood in Nepal. Journal of Biosocial Science. 2005; 37(02):143-62.

13. Faye A, Ndiaye P, Tal-Dia A, Bâ I.O. Facteurs déterminants le lieu d'accouchement chez des femmes ayant beneficie au moins d'une consultation prénatale dans une structure sanitaire (Sénégal). Revue d'épidémiologie et de santé publique 58 (2010) 323-339 
14. Manyeh et al. BMC Res Notes (2017) 10:268 DOI 10.1186/s13104-017-2591-z

15. Suvedi BK, Pradhan A, Barnett S, Puri M, Chitrakar S, Poudel P, et al. Nepal Maternal Mortality and Morbidity Study 2008/2009. Kathmandu, Nepal: Family Health division, Department of Health Services, Ministry of Health, Government of Nepal.; 2009. p.

16. Diallo $F$, Diallo $T$, Sylla $M$ et al. Problèmes médicaux et socioculturels de l'inadéquation entre les taux de consultation. http://www.santetropicale.com 